\title{
МОНИТОРНИГ ЗАПАДНОГО КУКУРУЗНОГО ЖУКА В РЕСПУБЛИКЕ МОЛДОВА
}

\author{
Рэйляну Н., Одобеску В. \\ Институт Генетики, Физиологии и Защиты Растений, Кишинев, Молдова \\ nata.raileanu@gmail.com
}

https://doi.org/10.53040/9789975347204.18

\begin{abstract}
The article presents the results of phytosanitary monitoring of western corn rootworm Diabrotica virgifera virgifera Le Conte in Repaublic of Moldova. It was noted that in some areas of the northern zone of the republic, the pest population exceeds the PED by 2-3 times. During the research period, the expansion of the pest's distribution area was recorded.
\end{abstract}

Key words: Diabrotica virgifera virgifera Le Conte, maize, distribution, pheromon traps.

\section{Введение}

В соответствие с данными Национального бюро статистики в РМ высевается около 535,6 тыс. га кукурузы с ежегодной перспективой роста посевных площадей. Культура кукурузы подвергается негативному воздействию вредных организмов как болезней, так и вредителей. Одним из особо опасных вредителей кукурузы является западный кукурузный жук, Diabrotica virgifera virgifera Le Conte. Повреждения, которые данный вредитель наносит кукурузе, приводят к существенным экономическим потерям сельхозпроизводства $[2,6,7]$.

Родиной западного кукурузного жука является территория США, где ежегодные потери урожая кукурузы и затраты на борьбу с ним составляют более 1 млрд долл. На территории Евросоюза данный вредитель отмечен в начале 1990-х годов, в соседней Украине первые особи были зафиксированы в 2001 году.

В соседней Румынии впервые данный вредитель зафиксирован в 1996 (Nădlac judeţul Arad), и быстро распространился на северо-восток, на востоке и юге страны. $[3,4,5]$. В странах ЕС западный кукурузный жук (Diabrotica virgifera virgifera Le Conte) был в числе карантинных объектов вплоть до 2016 года. Скорость пространственного распространения западного кукурузного жука в среднем составляет 20-80 км в течение года [6]. Из-за его высоких миграционных способностей вредитель распространился по территории практически всего Европейского союза, что привело к исключению вредителя Diabrotica virgifera virgifera Le Conte из списка карантинных видов (ALERT List).

Производители кукурузы терпят убытки от вредоносности западного кукурузного жука. Особенное негативное влияние проявляется на семеноводческих полях, т.к. взрослое насекомое практически полностью уничтожает рыльца у кукурузного початка, и это отражается на формировании и развитии семян в початке их качестве и количестве. 
В задачи исследований входило провести мониторинг вредителя, определить ареал его распространения и численность популяции.

\section{Материалы и методы}

В период 2018-2019 гг мы проводили наблюдения за развитием и распространением популяции западного кукурузного жука на территории РМ. Наблюдения вели визуально при обследовании полей кукурузы и прямыми учетами имаго, согласно методике [2], и при помощи феромонных ловушек. При визуальном учете были зафиксированы имаго западного кукурузного жука, как самки, так и самцы. Морфология самок и самцов ярко выражена и имеет характерные отличия по половому признаку. У самки на надкрыльях три продольных темно-синих, почти черных полоски (центральная проходит вдоль шва), а у самца полоски сливаются, но края надкрылий и их вершина остаются светлыми. Наличие ярко выраженных отличий по половому признаку способствует визуальной дифференциации имаго, и не затрудняет учет. На момент учета имаго вели себя очень активно перелетая с растения на растение, активно питались и спаривались.

В исследовании по мониторингу западного кукурузного жука (D. virgifera virgifera) использовали ловушки, содержащие феромон вредителя, 8-metil -2 decanol propanoat, синтезированный в лаборатории Protectia Integrata a Plantelor, grupa Substanţelor Biologici Active, IGFPP.

Ловушки были вставлены на высоте 1,5 м в полях кукурузы в северных районах республики. Клеевой вкладыш ловушки с диспенсером прикрепляли непосредственно к стеблю растения кукурузы.

Площадь исследуемых полей охватила такие районы как Drochia, Dondiușeni, Rîșcani, Soroca, Edineți и варьировала от 3 га до 200 га.

Надо отметить, что для Республики Молдова на данный момент нет разработанного и определенного экономического порога вредоносности (ЭПВ) для $D$. virgifera. Согласно исследованиям, проведенным в Румынии, установлены ЭПВ на уровне 5-10 имаго/растение [2, 6], в своих исследованиях мы руководствовались этими ЭПВ.

\section{Результаты и обсуждение}

В период проведения наблюдений численность западного кукурузного жука на полях кукурузы не была однозначной и в различных районах варьировала в зависимости от рельефа местности, удаленности поля кукурузы от других полей, ротации культур в конкретном хозяйстве.

При проведении учетов в 2018 году численность вредителя на уровне ЭПВ была зафиксирована в районах Rîșcani, s. Mihailenii Vechi, 8 ha- численность жуков при визуальных учетах достигла $-10,0$ экз/1 растение. В районе Ocnița, s. Gîrbova, площадь поля 47 hа- численность жуков достигла $-7,0$ экз/1 растений. В других районах численность была ниже, табл. 1.

При проведении мониторинга в 2018 году с помощью феромонных ловушек было отмечено, что на производственных семеноводческих полях кукурузы (Răuțel, S_200 ha) численность имаго на феромонную ловушку достигала 180-200 экз/ловушку. Данное количество вредителя является максимальным, которое было зарегистрировано в период наших исследований. В данном случае такая высокая плотность популяции вредителя на полях кукурузы объясняется тем, что хозяйство специализируется на получении семян кукурузы и возделывает ее по принципу монокультуры. Полученные 
нами результаты согласуются с литературными источниками, в которых отмечено негативное влияние ведения монокультуры кукурузы $[2,5,6]$.

Таблица 1. Средняя численность популяции вредителя в различных районах РМ, 2018,

\begin{tabular}{|c|c|c|c|c|c|c|c|c|}
\hline Дата & 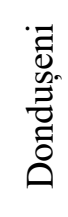 & 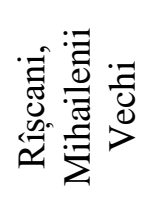 & 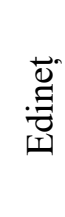 & . & 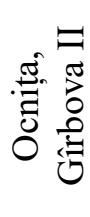 & 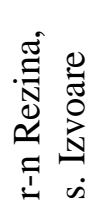 & 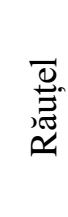 & 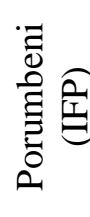 \\
\hline $10 / 07$ & 0 & 5,0 & 0 & 4,9 & 6,5 & 0 & 7,0 & 2,4 \\
\hline $19 / 07$ & 2,6 & 10,0 & 1,4 & 7,0 & 5,8 & 0 & 4,1 & 1,0 \\
\hline $03 / 08$ & 0 & 2,2 & 1 & 5,4 & 5,7 & 0 & 5,8 & - \\
\hline $24 / 08$ & 0 & 0 & 0 & 1,6 & 0,8 & 0 & 0 & - \\
\hline $30 / 08$ & 0 & 0 & 0 & 0 & 0 & 0 & 0 & - \\
\hline
\end{tabular}

В результате наблюдений 2019 г. за активностью и динамикой развития вредителя, анализом полученных данных можно сказать, что начало активности имаго жуков совпадает с началом формирования початков на растениях кукурузы, и выбрасыванием метелки. Взрослые особи повреждают листовую пластинку кукурузы, оставляя тонкую сетку. Такое повреждение листовой пластинки приводит к нарушению процессов фотосинтеза. Поврежденные листья высыхают, ослабляя растение в целом. Максимальное количество жуков было зафиксировано на кукурузе в r- 1 Dondușeni s. Briceva и составило 30 экз/1 растение, что существенно превышает уровень ЭПВ, рис 1.

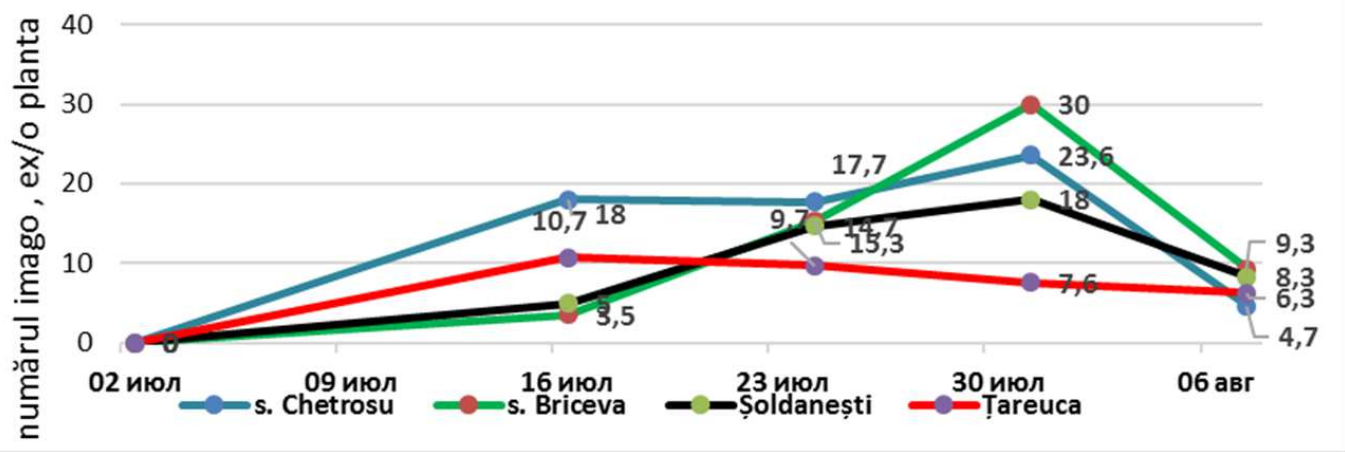

Рис. 1. Численность популяции D.virgifera имаго , экз/на 1 растение, 2019.

Данные прямых визуальных учетов имаго жуков согласуются с данными полученными в ходе феромонного мониторинга, представленного на рис. 2. Из представленной диаграммы видно, что максимальное количество вредителя наблюдалось в r- 1 Dondușeni s. Briceva, r-l Drochia, s. Chetrosu. В стадии развития початка имаго вредителя активно питаются нежными нитями рыльца кукурузы. Именно они являются основным пищевым субстратом для имаго западного кукурузного жука. При высокой численности жуков, рыльца кукурузы не успевают отрасти, что приводит к нарушениям процесса опыления и формирования зерен в початке. В дальнейшем, 
такие початки были мелкими, кривыми, озерненность не равномерная, что несомненно в итоге влияет на качество и количество урожая.

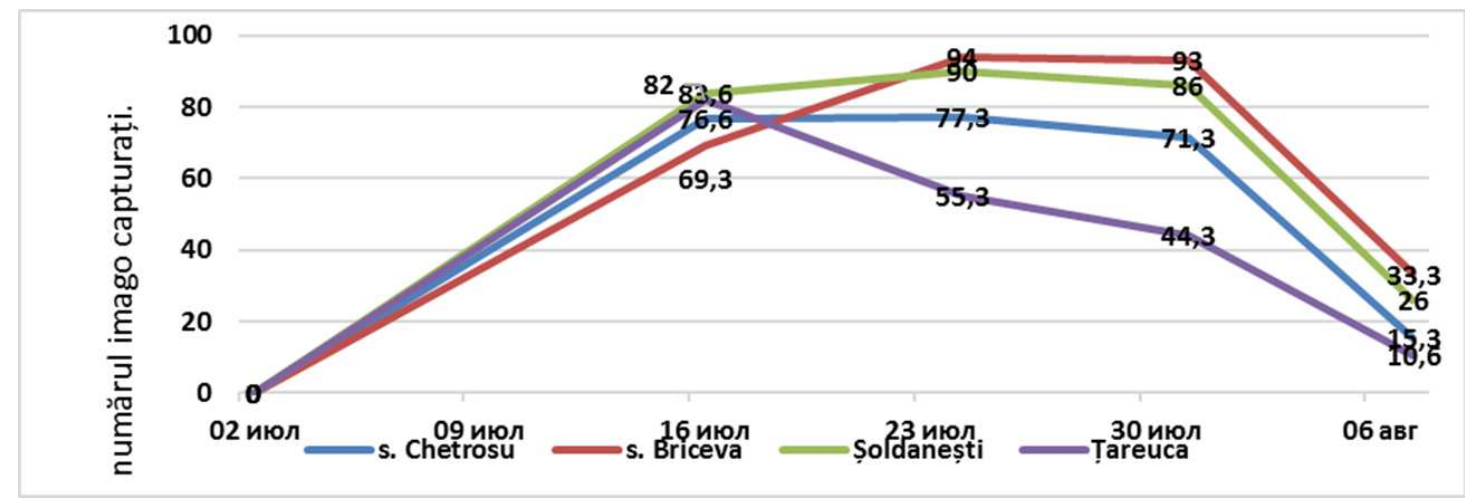

Рис. 2. Динамика отлова имаго D.virgifera в феромонную ловушку, экз./7 дней, 2019.

Также в результате наших наблюдений на обследуемых территориях в годы исследований зафиксировано появление вредителя в r-l Șoldanești (s. Țareuca) и r-l Rezina (s. Izvoare) в 2019 году, в то время как при мониторинге 2018 году на данных территориях вредитель не обнаружен. Эти результаты согласуется с литературными данными, в которых обращается внимание на высокие миграционные способности имаго вредителя- популяция в течение вегетационного периода кукурузы может переместится на расстояние до 80 км [2, 5], В совокупности с высокой плодовитостью самок эти оба фактора способствуют агрессивному распространению вредителя и «захвату» новых территорий.

На семеноводческих участках $\mathrm{s}$. Răuțel проведение химической обработки кукурузы инсектицидом против западного кукурузного жука способствовало снижению численности жука. На третий день после обработки численность вредителя снизилась с 18- 22 экз/растение до 4-5 экз/растение. Однако, спустя 4-6 дней численность имаго на растениях снова стала увеличиваться. Жуки мигрировали с соседнего поля, расположенного на расстоянии 2 км. И на дату учета 20.07. 2018 численность имаго варьировала в пределах 80-120экз/ловушку.

\section{Выводы}

На территории РМ происходит расширение ареала вредоносности западного кукурузного жука в северной зоне республики. Отмечено появление в r-l Șoldanești (s. T,areuca) и r-1 Rezina (s. Izvoare) в 2019г.

Численность популяции вредителя в отдельных районах северной зоны республики (r-1 Drochia, Dondușeni) превышает ЭПВ в 3раза.

Эффективность защитных мероприятий осложняется высокими миграционными способностей вредителя, а также ограниченным перечнем инсектицидов, зарегистрированных в национальном реестре.

\section{Библиография}

1. Ciobanu Cornelia, Ciobanu Gh și alt. Research on the establishment of chemical control technology on adults of species Diabrotica virgifera virgifera Le Conte (western corn rootworm/ Analele Universităţii din Oradea , Fascicula: Ecotoxicologie, Zootehnie şi Tehnologii de Industrie Alimentară, 2011 
2. Georgescu Emil, Cum să ținem în frâu Diabrotica virgifera? Publicat: 22 august,2016.https://www.revista-ferma.ro/articole/agronomie/cum-sa-tinem-in-fraudiabrotica-virgifera

3. Grozea, Ioana, 2003 - Biologia, ecologia şi combaterea viermelui vestic al rădăcinilor de porumb (Diabrotica virgifera virgifera Le Conte) în condiţiile Câmpiei de Vest. Teză de doctorat, USAB Timişoara, 215 pag

4. Pălăgeşiu, I., Sânea, N., Petanec, D., Buzăriu, A., Grozea, Ioana., Hâncu, Mariana, Muntean Adina, 1998 - Monotorizarea viermelui vestic al rădăcinilor de porumb (Diabrotica virgifera virgifera) în judeţul Timiş. Lucrări Ştiinţifice Protecţia plantelor. USAMVB Timişoara, XXX, II: 537-542.

5. Popov C., Ciobanu C., Balint A., Mureşan F. Cercetări privind combaterea larvelor speciei Diabrotica virgifera virgifera Le Conte. AN. I.N.C.D.A. Fundulea, VOL. 76, 2008. P 155- 165.

6. Evaluation of Integrated Pest Management for Western Corn Rootworm (WCR) in Central and Eastern Europe (GTFS/RER/017/ITA) Final Report of the Evaluation Mission March 2008. Coordinatory Government of Italy, FAO, 58p. http://www.fao.org/fileadmin/user_upload/oed/docs/GTFSRER017ITA_2008_ER.pdf 7. Voineac Vasile, Elisovețcaia Dina, Cristman Diana. Recomandări metodice privind monitorizarea, controlul și combaterea viermelui vestic al rădăcinilor de porumb Diabrotica virgifera virgifera Le Conte, Chişinău, 2016, 33 p. ISBN 978-9975-56-345-1. 